Tropical Journal of Pharmaceutical Research December 2011; 10 (6): 777-783

(C) Pharmacotherapy Group,

Faculty of Pharmacy, University of Benin

Benin City, 300001 Nigeria.

All rights reserved.

Available online at http://www.tjpr.org

Research Article

http://dx.doi.org/10.4314/tjpr.v10i6.11

\title{
Antioxidant and Antimicrobial Activities of Ethanol Extracts of Cynara Scolymus (Cynarae folium, Asteraceae Family)
}

\author{
Vamanu Emanuel $^{1^{\star}}$, Vamanu Adrian ${ }^{1}$, Niţă Sultana ${ }^{2}$ and Colceriu \\ Svetlana ${ }^{2}$ \\ ${ }^{1}$ Applied Biochemistry and Biotechnology Center - Biotehnol \& University of Agronomic Sciences and Veterinary \\ Medicine, Faculty of Biotechnology, Bd. Mărăşti no. 59, sector 1, ${ }^{2}$ National Institute of Chemical-Pharmaceutical \\ Research-Development - ICCF Bucharest, Vitan Road no. 112, sector 3, Bucharest, Romania.
}

\begin{abstract}
Purpose: Cynara scolymus is a medicinal plant frequently used in traditional medicine for stomach and liver diseases. The purpose of the study was to identify the most suitable extraction solvent for maximum antioxidant and antimicrobial effect of fluidized bed extracts.

Methods: The extracts were obtained by conventional maceration and fluidized bed extraction using 25, 50,75 and $97 \% \mathrm{v} / \mathrm{v}$ ethanol as solvent. The antioxidant effect of the extracts was determined by 2,2 diphenyl-1-picrylhydrazyl (DPPH) method. The quantities of phenols and flavonoids, and the reducing power of the extracts were also determined. The antimicrobial activity of the extracts was tested against different microbial strains using agar well diffusion method. The minimum inhibiting concentration (MIC) of the fluidized bed extract was also determined.

Results: The ethanol extract showed the highest antioxidant activity as well as yielded the largest quantity of polyphenolic compounds. For the extract obtained by fluidized bed technique, the optimum concentration of $10 \mathrm{mg} / \mathrm{ml}$ gave maximum antioxidant activity of $65.15 \%$. The MIC values obtained using the freeze-dried extract ranged from $5.0 \mathrm{mg} / \mathrm{ml}-15.0 \mathrm{mg} / \mathrm{ml}$. The extracts showed significant inhibitory activity against the tested strains of Listeria innocua CMGB 218, Bacillus cereus CMGB 215 with MIC of $5 \mathrm{mg} / \mathrm{ml}$ but showed MIC of $15 \mathrm{mg} / \mathrm{ml}$ for the other strains.

Conclusion: The results indicate that the freeze-dried extract from Cynara scolymus is capable of yielding nutritional supplements with antioxidant and antimicrobial activities.
\end{abstract}

Keywords: Artichoke, Freeze-drying, Fluidized bed extract, MIC 


\section{INTRODUCTION}

Artichoke (Cynara scolymus) is a species of perennial thistle, originating from the Mediterranean region, cultivated for the fleshy laminae in its bud as well as the edible thalami. It is a plant with large spiny leaves and a tall stem of up to $1.50 \mathrm{~m}$. The leaves are used for medicinal purposes (Folyum Cynarae) but must be picked when they are $30-35 \mathrm{~cm}$ long while the stalk and the main nerve are still tender; this makes it feasible for up to 4 - 5 harvests to be obtained per year.

The plant is used traditionally for the treatment of digestion-related illnesses, moderate hyperlipidemia as well as liver and bile diseases. It is thought that artichoke leaves are effective against liver and kidney diseases since they increase bile secretion and urine output, thus regulating the process of cholesterol formation and reducing blood sugar [1]. It is rich in cynarin and orthophenole constituents. Other phytochemicals present include cynaropicrin and sequiterpene lactones which possess both hypoglycemic and hypolipidemic activities. It was reported that artichoke is rich in fiber and low in fat. Thus, its health benefits were due to its high fiber content [24].

The purpose of this study was to characterize antimicrobial and antioxidant activity of the freeze-dried ethanol extracts of artichoke. Another was to determine its total phenol and flavonoid contents.

\section{EXPERIMENTAL}

\section{Plant material and its extraction}

The dried leaves of Cynara scolymus was provided by Fares Bio Vital Laboratories, Orastie, România. A quantity of $20 \mathrm{~g}$ of the powdered leaves was subjected to extraction by percolation with ethanol $(25,50,75$ and $97 \%$ v/v) for $2 \mathrm{~h}, 75^{\circ} \mathrm{C}$. In parallel, extraction by maceration with ultrapure water or $75 \%$ methanol was also carried out for $24 \mathrm{~h}$ at 150 rpm and $20{ }^{\circ} \mathrm{C}$. Thereafter, the most effective alcohol extraction fluid was used to generate an extract using a fluidized bed extractor (fexIKA 200, IKA Labortechnik). The extract was freeze-dried (Martin Christ Christ Alpha 1-2 LD) to obtain the dry extract. The alcohol extracts were concentrated in a rotary evaporator (Buchi R 210) under vacuum at $40{ }^{\circ} \mathrm{C}, 175 \mathrm{mbar}$ and $200 \mathrm{rpm}$. The elected concentrated solution was freeze-dried in a Martin Christ Christ Alpha 1-2 LD, to obtain the solid substance. The dried fractions were then re-dissolved in $80 \%$ ethanol to yield solutions containing 1.0, 2.5, 5.0, 10.0, 15.0, 20.0 and $25.0 \mathrm{mg}$ of extract per $\mathrm{ml}[5,6]$.

\section{Determination of total phenols content}

Total phenolic content was determined using Folin-Ciocalteu reagent. Varying concentrations of the plant extract were separately mixed with $5 \mathrm{ml}$ of Folin-Ciocalteu reagent (which ad been diluted 1:10 with distilled water). Sodium carbonate $(7.5 \%, 4 \mathrm{ml})$ was added to the mixture, shaken for a few seconds, and then incubated for $30 \mathrm{~min}$ at 40 ${ }^{0} \mathrm{C}$. The absorbance was read at $765 \mathrm{~nm}$ using a Helios spectrophotometer and against a reagent blank (ethanol:water, 50:50 $\mathrm{v} / \mathrm{v})$. The standard curve was prepared using $0,50,100,150,200,250 \mathrm{mg} / \mathrm{L}$ solutions of gallic acid in ethanol:water, 50:50 v/v. The total phenolic content was expressed in $\mathrm{mg} / \mathrm{g}$ gallic acid equivalent $[7,8]$.

\section{Determination of total flavonoid content}

A mixture consisting of $0.5 \mathrm{ml} 2 \%$ aluminium chloride $\left(\mathrm{AlCl}_{3}\right)$ in ethanol and $0.5 \mathrm{ml}$ of plant extract was prepared. It was left for $60 \mathrm{~min}$ at room temperature and the absorbance measured at $420 \mathrm{~nm}$ and against a reagent blank (ethanol). The calibration curve was prepared by preparing quercetin solutions at concentrations ranging from 12.5 to 100 $\mu \mathrm{g} / \mathrm{ml}$ in ethanol. The total flavonoid content was expressed as $\mathrm{mg} / \mathrm{ml}$ equivalent to quercetin $[9,10]$. 


\section{Determination of total antioxidant activity}

The antioxidant activity of the extract was measured by determining the 1,1-diphenyl2-picrylhydrazyl (DPPH) free radical scavenging capacity. The extract $(100 \mu \mathrm{l})$ was mixed with $3 \mathrm{ml}$ of ethanol solution of $0.004 \%$ DPPH and the absorbance was read at $517 \mathrm{~nm} 30 \mathrm{~min}$ later. Standard antioxidants (vitamin $\mathrm{E}$ and ascorbic acid, $1 \mathrm{mg} / \mathrm{ml}$ ) were used for comparison as positive control. $I_{50}$ value was calculated using the dose inhibition curve [5,11-13].

\section{Reducing power assay}

Various concentrations of the freeze-dried extract $(2.5 \mathrm{ml})$ were separately mixed with $2.5 \mathrm{ml}$ of $200 \mathrm{mmol} / \mathrm{l}$ sodium phosphate buffer ( $\mathrm{pH} 6.6)$ and $2.5 \mathrm{ml}$ of $1 \%$ potassium ferricyanide. The mixture was incubated at 50 ${ }^{0} \mathrm{C}$ for $20 \mathrm{~min}$. Next, $2.5 \mathrm{ml}$ of $10 \%$ trichloroacetic acid was added and the mixture centrifuged at $650 \mathrm{rpm}$ for $10 \mathrm{~min}$. The upper layer $(5 \mathrm{ml})$ was mixed with $5 \mathrm{ml}$ deionised water and $1 \mathrm{ml}$ of $0.1 \%$ of ferric chloride, and the absorbance measured at $700 \mathrm{~nm}$ : the higher the absorbance the higher the reducing power [11-13].

\section{Preliminary assessment of antibacterial activity of extract}

Escherichia coli CBAB 2, Bacillus cereus CMGB 215, Listeria innocua CMGB 218, Candida sp. ICCF 15, Staphylococcus aureus ATCC 6588, Pseudomonas aeruginosa ATCC 15442 and Candida albicans ATCC 20231 were used for the tests. For the aqueous and methanol extracts, each of the microbial strains was inoculated on a Petri plate into which LB /YPG-agar medium was previously poured. The plant extract $(20 \mu \mathrm{l})$ was added to the agar which was left to absorb the extract for $30 \mathrm{~min}$. Thereafter, the plates were incubated at 28 to $30^{\circ} \mathrm{C}$ for $24 \mathrm{~h}$. The zone of inhibition was analyzed using a special Colony Quant software. [14,15].

\section{Determination of minimum inhibitory concentration (MIC)}

The standard agar dilution protocol with doubling dilution was used. The extract was incorporated into nutrient agar at concentrations ranging from 2.5 to $20 \mathrm{mg} / \mathrm{ml}$. A control without the extract was also set up. Each of the test organisms $(10 \mu \mathrm{l})$, previously diluted to give $10^{6} \mathrm{CFU} / \mathrm{ml}$, was inoculated in the plate. The plates were incubated at $30{ }^{\circ} \mathrm{C}$ for $24 \mathrm{~h}$ in the first instance, and for another $24 \mathrm{~h}$, before the results were recorded after observing for growth. The minimum inhibitory concentration (MICs) of the extract for each test microorganism was taken as the agar plate having the lowest extract concentration without growth [15]. Ciprofloxacin and amoxycillin were used as standard antimicrobial agents and tested along with the extract.

\section{Statistical analysis}

All experiments were performed at least in triplicate and the results are presented as mean \pm SD (standard deviation). Statistical analysis was carried out using Statistica 6.0 (StatSoft Inc, Tulsa, USA). Pearson correlation test was conducted to determine correlations between the variables. Significant level was set at $p \leq 0.05$ [16].

\section{RESULTS}

\section{Phenolic content}

The total phenolic content of the extracts from medicinal plant species varies according to the solvent used and and its alcohol concentration. Alcohol extracts of artichoke obtained by simple extraction (i.e., nonfluidized method) contained high quantities of phenolic compounds. Maximum amount of phenolics was obtained using $75 \%$ ethanol as the extraction solvent and corresponded to $50 \mathrm{mg} / \mathrm{g}$ equivalent of gallic acid. Phenolic content increased with increase in ethanol concentration except that at $97 \%$ ethanol, 
the phenolics dropped by $2.77 \%$ compared to the extract obtained with $75 \%$ ethanol. When $75 \%$ methanol and water were used as extraction solvent, the decrease in phenol content (compared with $75 \%$ ethanol extract) was 22.9 and $69.9 \%$, respectively. The least phenolic content resulted when $25 \%$ ethanol was used as the extracting solvent, yielding $9.96 \mathrm{mg} / \mathrm{g}$ equivalent of gallic acid.

\section{Flavonoid content}

The total flavonoid content in the extracts varied between $104.4 \mathrm{mg}$ equivalent of quercetin $/ \mathrm{ml}$ for distilled water as the extracting solvent, to $313.65 \mathrm{mg} / \mathrm{ml}$ equivalent of quercetin for $75 \%$ methanol. Flavonoid content also varied according to the solvent used and its ethanol concentration. The maximum was 271.5 $\mathrm{mg} / \mathrm{ml}$ quercetin for $75 \%$ ethanol (the highest for ethanol-based solvents), but this value was $13.43 \%$ lower than that for methanol (Table 1).

\section{Antiozidant activity}

The extract obtained with $75 \%$ ethanol demonstrated the highest inhibition of DPPH radicals. With regard to ethanol, the higher the ethanol content, the greater the inhibition capacity. Beyond an ethanol concentration of $75 \%$, the inhibition capacity of DPPH radicals dropped by approximately $3 \%$ compared with $97 \%$ ethanol.

\section{Reducing power}

Reducing power (Table 1) is a measure of antioxidant potential. Increase in ethanol concentration resulted in an increase in reducing power, except for $97 \%$ ethanol, which showed a drop of $16.1 \%$ in relation to $75 \%$ ethanol. Methanol showed equivalent reducing power to ethanol when used at the same concentration. However, water continued to manifest as the weakest extraction solvent, with a decrease of $73.7 \%$ compared to the highest values.

\section{Antimicrobial activity}

The results of the antimicrobial test are shown in Table 2. Ethanol (25\%) extract and that of $75 \%$ methanol showed the weakest antimicrobial activity, except against the Listeria innocua CMGB 218, with an inhibition zone of at least $1.0 \mathrm{~cm}$. The most efficient extract was the one obtained with $97 \%$ ethanol, with an maximum inhibition zone of $1.7 \mathrm{~cm}$ against Escherichia coli CBAB 2 and Listeria innocua CMGB 218. In general, $75 \%$ ethanol may be considered to be a good solvent, since extracts obtained with it were not only active against Pseudomonas aeruginosa ATCC 15442 and Staphylococcus aureus ATCC 6588, but also against Candida albicans ATCC 20231, with an inhibition zone of $1.5 \mathrm{~cm}$. Pseudomonas aeruginosa ATCC 15442 and Staphylococcus aureus ATCC 6588 were not inhibited by the extract obtained with distilled water, 75 $\%$ methanol as well as by 25 and $50 \%$ ethanol. The only exception was Staphylococcus aureus ATCC 6588 with an

Table 1: Total phenolic and flavonoid contents, as well as antioxidant activity and reducing power of extracts of Cynara scolymus obtained by simple extraction procedure

\begin{tabular}{lcccc}
\hline Solvent & $\begin{array}{c}\text { Total phenolic } \\
\text { content } \\
\text { (mg/g gallic acid) }\end{array}$ & $\begin{array}{c}\text { Flavonoid } \\
\text { content } \\
(\mathrm{mg} / \mathrm{ml} \text { quercetin) }\end{array}$ & $\begin{array}{c}\text { Antioxidant } \\
\text { activity }(\%)\end{array}$ & $\begin{array}{c}\text { Reducing power } \\
\text { (OD 700 nm) }\end{array}$ \\
\hline Ultrapure water & $15.2 \pm 0.03$ & $104.4 \pm 0.04$ & $18.17 \pm 0.02$ & $0.88 \pm 0.01$ \\
$75 \%$ methanol & $38.90 \pm 0.04$ & $313.7 \pm 0.1$ & $50.38 \pm 0.02$ & $3.36 \pm 0.02$ \\
$25 \%$ ethanol & $9.96 \pm 0.04$ & $106.2 \pm 0.0$ & $31.29 \pm 0.04$ & $2.37 \pm 0.02$ \\
$50 \%$ ethanol & $23.42 \pm 0.04$ & $211.5 \pm 0.0$ & $39.38 \pm 0.04$ & $3.30 \pm 0.01$ \\
$75 \%$ ethanol & $50.50 \pm 0.00$ & $271.5 \pm 0.0$ & $50.38 \pm 0.04$ & $3.36 \pm 0.04$ \\
$97 \%$ ethanol & $49.1 \pm 0.04$ & $179.4 \pm 0.0$ & $48.78 \pm 0.05$ & $2.82 \pm 0.03$ \\
\hline
\end{tabular}


Emanuel et al

Table 2: Antimicrobial activity (cm, zone of inhibition) of extracts of Cynara scolymus

\begin{tabular}{|c|c|c|c|c|c|c|c|}
\hline \multirow[b]{2}{*}{$\begin{array}{l}\text { Extraction } \\
\text { solvent }\end{array}$} & \multicolumn{7}{|c|}{ Microorganism } \\
\hline & $\begin{array}{c}\text { Escherichia } \\
\text { coli CBAB } \\
2\end{array}$ & $\begin{array}{c}\text { Bacillus } \\
\text { cereus } \\
\text { CMGB } \\
215\end{array}$ & $\begin{array}{c}\text { Listeria } \\
\text { innocua } \\
\text { CMGB } \\
218\end{array}$ & $\begin{array}{l}\text { Candida } \\
\text { specie } \\
\text { ICCF15 }\end{array}$ & $\begin{array}{c}\text { Candida } \\
\text { albicans } \\
\text { ATCC } \\
20231\end{array}$ & $\begin{array}{c}\text { Pseudomonas } \\
\text { aeruginosa } \\
\text { ATCC } 15442\end{array}$ & $\begin{array}{c}\text { Staphylococcus } \\
\text { aureus ATCC } \\
6588\end{array}$ \\
\hline $\begin{array}{l}\text { Ultrapure } \\
\text { water }\end{array}$ & $0.80 \pm 0.02$ & - & $0.90 \pm 0.03$ & $0.80 \pm 0.01$ & - & - & - \\
\hline $\begin{array}{l}75 \% \\
\text { methanol }\end{array}$ & - & $1.00 \pm 0.03$ & $1.00 \pm 0.02$ & - & $1.00 \pm 0.00$ & - & $0.80 \pm 0.01$ \\
\hline $\begin{array}{l}25 \% \\
\text { ethanol }\end{array}$ & - & - & $1.10 \pm 0.00$ & - & - & - & - \\
\hline $\begin{array}{l}50 \% \\
\text { ethanol }\end{array}$ & - & $0.90 \pm 0.20$ & $1.50 \pm 0.03$ & $0.80 \pm 0.04$ & $0.50 \pm 0.04$ & - & - \\
\hline $\begin{array}{l}75 \% \\
\text { ethanol }\end{array}$ & $1.50 \pm 0.02$ & $1.10 \pm 0.00$ & $1.70 \pm 0.00$ & $1.00 \pm 0.00$ & $1.50 \pm 0.02$ & $1.10 \pm 0.04$ & $1.20 \pm 0.03$ \\
\hline $\begin{array}{l}97 \% \\
\text { ethanol }\end{array}$ & $1.70 \pm 0.03$ & $1.50 \pm 0.04$ & $1.70 \pm 0.02$ & $1.20 \pm 0.04$ & $1.00 \pm 0.02$ & $0.70 \pm 0.05$ & $1.10 \pm 0.04$ \\
\hline
\end{tabular}

Table 3: Antioxidant activity, total phenolic content and flavonoid content of various freeze-dried extract concentrations

\begin{tabular}{lccc}
\hline $\begin{array}{c}\text { Freeze-dried extract } \\
\text { concentration }\end{array}$ & Antioxidant activity (\%) & $\begin{array}{c}\text { Total phenolic content } \\
\text { (mg/g gallic acid) }\end{array}$ & $\begin{array}{c}\text { Flavonoid content } \\
\text { (mg/ml quercetin) }\end{array}$ \\
\hline 1 & $10.98 \pm 0.0$ & $4.12 \pm 0.03$ & $63.5 \pm 0.03$ \\
2.5 & $31.17 \pm 0.04$ & $5.14 \pm 0.03$ & $65.85 \pm 0.04$ \\
5 & $46.24 \pm 0.02$ & $6.58 \pm 0.04$ & $105 \pm 0.04$ \\
10 & $65.15 \pm 0.04$ & $11.5 \pm 0.03$ & $195.6 \pm 0.04$ \\
15 & $51.55 \pm 0.03$ & $10.02 \pm 0.01$ & $313.5 \pm 0.03$ \\
20 & $41.89 \pm 0.01$ & $27.02 \pm 0.01$ & $396.75 \pm 0.03$ \\
25 & $34.18 \pm 0.01$ & $30.38 \pm 0.03$ & $430.5 \pm 0.03$ \\
\hline
\end{tabular}

Note: The antioxidant activity of the positive controls - vitamin $E$ and ascorbic acid (1 $\mathrm{mg} / \mathrm{ml}$ each) - were $88.7 \pm 0.07$ and $70.37 \pm 0.20 \%$, respectively

inhibition zone of $0.8 \mathrm{~cm}$ for $75 \%$ methanol extract.

\section{Antioxidant activity of freeze-dried extract}

The antioxidant activity data for freeze-dried artichoke extract, which were obtained by the DPPH assay, are indicated in Table 3. Antioxidant activity increased with increase in extract concentration. The degree of discoloration of the extract indicates the potential for binding free radicals present by the freeze-dried extract. Extract concentrations $>10 \mathrm{mg} / \mathrm{ml}$ showed a decrease in antioxidant activity. The decrease occurred gradually, by approximately $20 \%$, to a concentration of $50 \%$. At the said concentration, antioxidant activity was obtained representing approximately 77 $\%$ of ascorbic acid activity (84 \%) and $73 \%$ of $\alpha$-tocopherol $(88.5 \%)$, at a concentration of $1 \mathrm{mg} / \mathrm{ml}$. For this type of extract, the increase in concentration did not indicate a direct increase of antioxidant capacity. The $\mathrm{IC}_{50}$ value of artichoke extract was of 5.9 $\mathrm{mg} / \mathrm{ml}$, which confirmed the presented data. 
Table 4: Minimum inhibitory concentration (MIC) of freeze-dried artichoke extract, obtained by fluidized bed extraction, against some test microorganisms

\begin{tabular}{lccc}
\hline Strain & MIC $(\mathrm{mg} / \mathrm{ml})$ & $\begin{array}{c}\text { Ciprofloxacin } \\
(\mathrm{mg} / \mathrm{ml})\end{array}$ & $\begin{array}{c}\text { Amoxycillin } \\
(\mathrm{mg} / \mathrm{ml})\end{array}$ \\
\hline Escherichia coli CBAB 2 & 15 & 5 & 15 \\
Listeria innocua CMGB 218 & 5 & 5 & 15 \\
Bacillus cereus CMGB 215 & 5 & 5 & 15 \\
Staphylococcus aureus ATCC 6588 & 5 & 5 & 7.5 \\
Pseudomonas aeruginosa ATCC 15442 & 15 & 5 & - \\
Candida albicans ATCC 20231 & 15 & - & - \\
Candida sp. ICCF15 & 15 & - & - \\
\hline
\end{tabular}

Total phenolic content varied between 2.12 and $30.38 \mathrm{mg} / \mathrm{g}$ equivalent of gallic acid and increased with increase in extract concentration (see Table 3). Similarly, flavonoids content also increased as extract concentration increased. The fluidized bed extract particularly showed high flavonoids content ranging from 63.5 to $430.5 \mathrm{mg} / \mathrm{ml}$ quercetin. Clearly, the use of fluidized bed extraction enhanced both the phenolic and flavonoid contents of the extract a well as its antioxidant activity.

Table 4 shows that the freeze-dried extract obtained by fluidized bed extraction had a powerful antimicrobial effect. The most sensitive strains were Listeria innocua CMGB 218 and Bacillus cereus CMGB 215 (MIC, 5 $\mathrm{mg} / \mathrm{ml}$ ). For all the other strains, including yeasts such as Candida, MIC was $15 \mathrm{mg} / \mathrm{ml}$.

\section{DISCUSSION}

Polyphenolic compounds, often present in plant extracts, have various biological activities among which are antioxidant activity [17]. There is a direct relation between antioxidant activity and the reducing power. Furthermore, the direct relationship between reducing power and antioxidant activity has also been correlated with extract concentration and extraction method $[6,16]$.

There was no direct relationship between phenolic content and antioxidant activity. Although, Yang et al [12] found such a direct relation but their work pertained to medicinal mushroom extracts. However, for medicinal plant extracts, the studies of Bajpai et al [8] and Sengul et al [7] confirmed our own observations. These studies indicate that phenolics have varying antioxidant behavior which depends on the type of compound.

Enhancement of extraction from plant materials by the fluidized bed method indicate that the technique promotes the release of various phenolic compounds. The high flavonoid content of the fliuidized bed extracts is significant in view of the claimed vasculoprotector and antiatherosclerotic effects of these compounds [4]. Thus artichoke extracts may be of use in reducing blood lipids, and when taken together with its antioxidant property, the extract could be potentially useful for cardiovascular protection. Based on the high levels obtained, it seems that a significant proportion of the pharmacological effect of the plant is due to flavonoids since the therapeutic effects of artichoke are ascribed to the presence of flavonoids.

\section{CONCLUSION}

The fluidized-bed ethanol artichoke extract showed varying antioxidant and antimicrobial activities. Although the values of these parameters were high, the flunctuation in antioxidant activity observed indicates that further studies are required to isolate the active principles of the extract. However, the extract's antimicrobial activity justifies its use in traditional medicine for the treatment of certain digestive diseases caused by pathogenic microbial strains. 


\section{ACKNOWLEDGMENT}

The study was financed through a project of National Plan for Research, Development and Innovation II no. 62-069/2008.

\section{REFERENCES}

1. Löhr G, Deters A, Hensel A. In vitro investigations of Cynara scolymus $L$. extract on cell physiology of HepG2 liver cells. Braz $J$ Pharm Sci 2009; 45: 201-208.

2. Nazni P, Poongodi VT, Alagianambi $P$, Amirthaveni M. Hypoglycemic and Hypolipidemic Effect of Cynara Scolymus among Selected Type 2 Diabetic Individuals. Paj J Nutr 2009; 5: 147-151.

3. Gebhard R. Anticholestatic activity of flavonoids from artichoke (Cynara scolymus L.) and their metabolites. Med Sci Mon 2001; 7: 316-320.

4. Li H, Xia N, Brausch I, Yao Y,Ulrich F, Flavonoids from Artichoke (Cynara scolymus L.) UpRegulate Endothelial-Type Nitric-Oxide Synthase Gene Expression in Human Endothelial Cells. J Pharmacol Exp Ther 2004; 310: 926-932.

5. Sreenivasan S, Ibrahim D, Mohd Kassim MJN. Free radical Scavenging Activity and Total Phenolic Compounds of Gracilaria changi. Int J Nat Eng Sci 2007; 1: 115-117.

6. Vamanu $E$, Vamanu A, Nita $S$. The obtaining of an antioxidant based on a Rosmarinus officinalis freeze-dried extract. Int $J$ Pharmacol 2010; 6: 387 - 392.

7. Sengul M, Yildiz $H$, Gungor $N$, Cetin B, Eser Z, Ercisli S. Total phenolic content, antioxidant and antimicrobial activities of some medicinal plants. Pak J Pharm Sci 2009; 22: 102-106.

8. Bajpai M, Pande A, Tewari SK, Prakash D. Phenolic contents and antioxidant activity of some food and medicinal plants. Int J Food Sci Nutr 2005; 56: 287-291.

9. Sathishkumar $T$, Baskar $R$, Shanmugam $S$, Rajasekaran P, Sadasivam S, Manikandan V. Optimization of flavonoids extraction from the leaves of Tabernaemontana heyneana Wall. using L16 Orthogonal design. Nature and Science 2008; 6: 10-21.

10. Raquibul Hasan SM, Jamila M, Majumder MM, Raushanara A, Hossain MM, Mazumder MEH, Alam MA, Jahangir R, Rana MS, Arif $M$, Rahman S, Analgesic and Antioxidant Activity of the Hydromethanolic Extract of Mikania scandens (L.) Willd. Leaves. Am J Pharm Toxico 2009; 13: 41-7.

11. Koksal E, Bursal E, Dikici E, Tozoglu F, Gulcin I, Antioxidant activity of Melissa officinalis leaves. J Med Plants Res 2011; 5: 217-222.

12. Yang JH, Lin HC, Mau JL. Antioxidant properties of several commercial mushrooms. Food Chem. 2002; 77: 229-235.

13. Rajeshwar Y, Senthil Kumar GP, Gupta M, Mazumder UK. Studies on in vitro antioxidant activities of methanol extract of Mucuna pruriens (fabaceae) seeds. Eur $J$ Drug Res 2005; 13: 31-39.

14. Seyyed MS, Niknejad M, Darabpoor I, Motamedi H. Antibacterial Activity of Hydroalcoholic Extract of Callistemon citrinus and Albizia lebbeck. Am J Appl Sci 2010; 7: 13-16.

15. Oboh IE, Akerele JO, Obasuyi O. Antimicrobial activity of the ethanol extract of the aerial parts of sida acuta burm.f. (malvaceae). Trop J Pharm Res 2007; 6: 809-813.

16. Živković J, Zeković Z, Mujić I, Vidović S, Cvetković $D$, Lepojević Ž, Nikolić G, Trutić $N$. Scavenging Capacity of Superoxide Radical and Screening of Antimicrobial Activity of Castanea sativa Mill. Extracts. Czech J Food Sci 2010; 28: 61-68.

17. Hasan MdK, Kabir AKL, Mistry S. Chemical and Biological Investigation of Leaves of Polygonum plebeju., S J Pharm Sci 2009; 2: 66-71. 